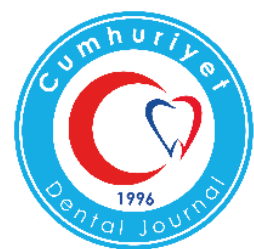

\title{
IN-VITRO EVALUATION OF THE MICROHARDNESS AND FLUORIDE RELEASING PROPERTIES OF CHLORHEXIDINE+BENZALKONIUM CHLORIDE MIXTURES INCORPORATED INTO CONVENTIONAL GLASS IONOMER CEMENT
}

\author{
Geleneksel Cam İyonomer İçerisine Katılmış Klorheksidin+Benzalkonyum Klorid \\ Karışımının Mikrosertlik ve Florür Salım Özelliklerinin İn-vitro Değerlendirilmesi
}

\author{
Tamer TÜZÜNER
}

\section{Makale Kodu/Article Code : 410459 \\ Makale Gönderilme Tarihi $\quad$ :28.03.2018 \\ Kabul Tarihi}

\begin{abstract}
Objectives: In atraumatic restorative dentistry, the usage of antibacterial materials with glass ionomer cements (GICs) are considered as beneficial for eliminating the residual caries under the restoration. However, adding such antibacterials to the GIC could lead harmful effects on the pyhsical and chemical properties of the cement structure. Thus, it was aimed to analyze the microhardness and fluoride releasing alterations of chlorhexidine $(\mathrm{CHX})+$ benzalkonium chloride $(\mathrm{BC})$ antibacterial $(\mathrm{AB})$ mixtures which were added to the powder of conventional glass ionomer cement (CGIC).
\end{abstract}

Material and Method: The powders of $\mathrm{AB}(1 \% \mathrm{CHX}+1 \% \mathrm{BC})$ were added to the powders of CGIC and selected as experimental group (EXP). Antibacterial free CGIC was assigned as control (CNT). Vickers micro hardness measurements (VHN; $n=10$, for each group) and fluoride releasing (FR; $n=10$, for each group) amounts were calculated at days 1 and 7. Mann Whitney U and Wilcoxon tests were used for statistical analysis at a significance level of $\mathrm{p}<0.05$.

Results: Significantly higher VHN values were obtained in CNT compared to the EXP group at days $1(\mathrm{p}<0.001)$ and $7(\mathrm{p}<0.001)$. Significantly increased VHN values observed at day 7 compared to the day 1 in CNT $(\mathrm{p}<0.01)$ and $\operatorname{EXP}(\mathrm{p}<0.05)$ groups. The FR amounts indicated no significant differences between CNT and EXP at days $1(p>0.05)$ and $7(p>0.05)$. Significantly higher FR values were shown at day 7 compared to the day 1 in CNT $(\mathrm{p}<0.01)$ and $\operatorname{EXP}(\mathrm{p}<0.01)$ groups.

Conclusions: It can be concluded that, even the usage of $1 \% \mathrm{CHX}$ $+1 \%$ BC mixtures with the CGIC may be more problematic for microhardness values but acceptable for fluoride releasing properties compared to the CNT group, reasonable time dependent alterations observed in VHN and FR results should not be overlooked for future studies.

Key Words: conventional glass ionomer cement, chlorhexidine, benzalkonium chloride, surface microhardness, fluoride

\begin{abstract}
ÖZET
Amaç: Atravmatik restoratif tedavide, antibakteriyel materyallerin cam iyonomer siman (CIS) ile birlikte kullanımının restorasyon altındaki bakterilerin eliminasyonunda yararlı olduğu düşünülmektedir. Bununla birlikte çeşitli antibakteriyel materyallerin CIS'lara eklenmesi sonucunda simanın yapısında zararlı fiziksel ve kimyasal değişimler oluşabilir. Bu nedenle, bu araştırmada Klorheksidin (KHX)+ Benzalkonyum klorit (BK) karışımı geleneksel cam iyonomer siman (GCIS)'ın tozunun içerisine katılarak mikrosertlik ve flüorür salım özelliklerindeki değişimlerin analiz edilmesi amaçlandı.

Gereç ve Yöntem: \%1 KHX+\%1 BK karışımı GCIS'nın tozu içerisine katılarak deney grubu oluşturuldu (DNY). Antibakteriyel içermeyen GCIS ise kontrol grubu olarak belirlendi (KNT). Vickers mikrosertlik ölçümleri (VMS; $\mathrm{n}=10$; her bir grupta) ve florür salım ( $\mathrm{FS} ; \mathrm{n}=10$, her bir grupta) miktarları 1 ve 7. günlerde hesaplandı. Mann Whitney $U$ ve Wilcoxon testleri ile $\mathrm{p}<0.05$ anlamll1ık düzeyinde değerlendirildi $(\mathrm{p}<0.05)$. Bulgular: Birinci $(p<0.001)$ ve 7 . $(p<0.001)$ günlerde KNT grubunda DNY grubu ile karşılaştırıldığında istatistiksel olarak anlamlı daha yüksek VMS değerleri elde edildi. Yedinci gün değerleri 1.gün ile karşılaştırıldığında KNT $(\mathrm{p}<0.01)$ ve DNY $(\mathrm{p}<0.05)$ gruplarında anlamlı düzeyde artan VMS değerleri gözlendi. Florür salım miktarları 1. ve 7. Günlerde KNT ( $p>0.05$ ) ve DNY ( $p>0.05)$ grupları arasında anlamlı farklılık göstermedi. Yedinci gün değerleri 1.gün ile karşılaştırıldığında ise KNT $(\mathrm{p}<0.01)$ ve DNY $(\mathrm{p}<0.01)$ gruplarında anlamlı düzeyde daha yüksek FS değerleri gösterdi.

Sonuç: \%1 KHX+\%1 BK karışımının GCis ile birlikte kullanımın mikrosertlik değerleri için problemli ancak florür salım özellikleri için KNT grubuna göre daha az ciddi sorun oluşturmasının yanısıra, VMS ve FS sonuçlarının zamana bağlı olarak değişimlerinin kabul edilebilir olduğu konusunun, gelecekte yapılacak olan araştırmalarda göz ardı edilmemesi gerektiği kanısına varılabilir.
\end{abstract}

Anahtar kelimeler: geleneksel cam iyonomer siman, klorheksidin, benzalkonyum klorid, yüzey mikrosertliği, florür 


\section{INTRODUCTION}

It has been well known that the atraumatic restorative treatment (ART) is a less invasive way of excavate the carious dentine by hand instruments and restoring the cavities with glass ionomer cement (GIC). ${ }^{1-3}$ Since the carious tissue could not be completely eliminated in ART procedure, the potential fluoride releasing properties of GICs could not be sufficient in terms of inhibiting residual bacteria. ${ }^{4-6}$ To overcome the residual caries problem, previous studies reported that the incorporation of antibacterial materials such as chlorhexidine (CHX), cetrimide, cetylpyridinium chloride, benzalkonium chloride (BC) and any other substances, distinctly or in different combinations form into GICs could enhance antimicrobial properties against the caries associated bacteria. ${ }^{7-21}$

It has been emphasized that the basic structure of the material should not be seriously impaired when GICs are modified with the various concentrations of the antibacterial materials while enhancing antimicrobial efficiency. It is also clear in the literature that the usage of microhardness testing in different time intervals are very useful to test the alterations for antibacterial/glass ionomer combinations. ${ }^{7,8,10-12,15,16,19,20-21 \quad \text { However, }}$ adding various antibacterial components may commonly impair basic structural surface hardness values..$^{7,8,10,15,16,19}$ Moreover, chemical properties such as fluoride releasing profile of antibacterial/GIC combinations have been also tested in previous reports by using the fluoride ion-selective electrode and investigators reported such conflicting results in different conditions. ${ }^{17,19,20}$

Because of the above reasons; the aim of this study is to analyze the chlorhexidine (CHX)/benzalkonium chloride (BC) mixtures incorporated into the conventional glass ionomer cement (CGIC) by means of the microhardness and fluoride releasing alterations from days 1 to 7 .

\section{MATERIAL AND METHOD}

Ketac Molar (KM) (3M ESPE, Seefeld, Germany) which is a conventional glass ionomer cement used as a control group (CNTantibacterial free). Powders mixing of $1 \%$ Chlorhexidine diacetate (CHX) (Serva, Heidelberg, Germany)/ 1\% Benzalkonium chloride (BC) (Sigma-Aldrich, Taufkirchen Germany) was incorporated into the powder of conventional GICs (w/w) and served as experimental group (EXP-antibacterial added; a total of $2 \%$ concentration).

\section{Microhardness Test}

A total of 20 ( $n=10$; for each group) GIC samples $5 \mathrm{~mm}$ in diameter and $2 \mathrm{~mm}$ deep were prepared. Samples were prepared according to the instructions of manufacturers' directions. After the completion of setting reaction, samples were placed into the plastic tubes containing distilled water and stored at $37^{\circ} \mathrm{C}$ for 24 hours. After 24 hours, the measurements of Vickers microhardness (HMV-700, Shimadzu, Tokyo, Japan) numbers were carried out by dividing the each sample into four quadrants and four different measurements were performed under a load of $200 \mathrm{~g}$ and 10 seconds out on the top of the surface of each specimen. The average of the measurements were recorded as the Vickers microhardness of the material as day 1 values. Above mentioned same procedures were also performed again after storing the samples in distilled water up to day 7 .

\section{Fluoride Releasing Measurements}

Glass ionomer cement samples of $5 \mathrm{~mm}$ in diameter and $2 \mathrm{~mm}$ in depth (a total of 20 samples; $n=10$ for each group) were prepared for fluoride determination. Samples were stored in distilled water at $37^{\circ} \mathrm{C}$ for 24 hours. Fluoride standards were prepared from $100 \mathrm{ppm}$ standard solution by dilution with deionized water and applied for the calibration of the $\mathrm{F}^{-}$ion selective electrode (Thermo-Orion, Massachusetts, USA). The potential measurements were carried out at room temperature with an 
ionmeter (Thermo-Orion, Massachusetts, USA). A calibration curve was constituted with the values of the known standards. Each measurement was performed in triplicate to check the reliability of the procedure. The data provided from the cement samples were calculated according to this curve. The cumulative fluoride concentrations were evaluated at days 1 and 7 by renewing batch procedure. Between the periods, the samples were stored in distilled water. The results were evaluated in terms of $\mu \mathrm{g} / \mathrm{mm} 2$ by calculating the amount of fluoride ion released from the sample surface to the unit area.

\section{Statistical analysis}

Statistical data analysis was performed with SPSS for 17.0 Windows (SPSS Inc., Chicago, IL, USA). Shapiro Wilk test was used for testing the normality of data. MannWhitney U-test was used for the comparison of CNT and EXP groups at days 1 and 7 . To compare the time dependent changes for individual group (CNT and EXP), Wilcoxon signed rank test was used. The confidence interval of $95 \%(\mathrm{p}<0.05)$ was chosen as significantly different for the all tests.

\section{RESULTS}

Significantly higher microhardness values were obtained in CNT compared to the EXP group for both days $1(\mathrm{p}<0.001)$ and $7(\mathrm{p}<0.001)$. Significantly higher microhardness values were also obtained at day 7 when compared to with the 1 day measurements for $\mathrm{CNT}(\mathrm{p}=0.005)$ and EXP $(p=0.022)$ groups, distinctly (Table 1$)$.

Table 1. Microhardness values; median (min-max) and comparison of CNT and EXP groups

\begin{tabular}{|c|c|c|c|}
\hline \multirow[b]{2}{*}{$\begin{array}{l}\text { Groups } \\
(n=10)\end{array}$} & \multicolumn{3}{|c|}{ Vickers Microhardness Values median (min-max) } \\
\hline & Day 1 & Day 7 & $p$ value \\
\hline CNT & $\begin{array}{c}67.46^{\mathrm{A}, \mathrm{a}} \\
(61.66-71.60) \\
59.94^{\mathrm{B}, \mathrm{c}}\end{array}$ & $\begin{array}{c}76.71^{\mathrm{A}, \mathrm{b}} \\
(70.3-78.36) \\
64.41^{\mathrm{B}, \mathrm{d}}\end{array}$ & $\mathrm{p}=0.005 ; \mathrm{p}<0.01$ \\
\hline EXP & $(51.32-63.88)$ & $(60.35-69.13)$ & $\mathrm{p}=0.022 ; \mathrm{p}<0.05$ \\
\hline$p$ value & $\mathrm{p}<0.001$ & $\mathrm{p}<0.001$ & \\
\hline $\begin{array}{l}\text { *In each } \\
\text { superscri } \\
p<0.001) \\
\text { different } \\
\text { CNT }\left(^{a-b} p\right.\end{array}$ & $\begin{array}{l}\text { significant } d \\
\text { tal letters be } \\
\text { ach row, sign } \\
\text { ript lower-ca } \\
; p<0.01) \text { and }\end{array}$ & $\begin{array}{l}\text { ences were } g \\
\text { en CNT and } \\
\text { ant difference } \\
\text { etters betwee } \\
P\left({ }^{c-d} p=0.02\right.\end{array}$ & $\begin{array}{l}n \text { with different } \\
X P \text { groups }\left({ }^{A-B}\right. \\
\text { vere given with } \\
\text { lays } 1 \text { and } 7 \text { in } \\
00.05) \text { groups. }\end{array}$ \\
\hline
\end{tabular}

No significant differences were observed between CNT and EXP groups at days 1 $(\mathrm{p}=0.494)$ and $7(\mathrm{p}=0.211)$ according to the fluoride releasing amounts. Significantly higher fluoride releasing values were obtained at day 7 compared to the day 1 in CNT $(\mathrm{p}=0.005)$ and EXP groups $(\mathrm{p}=0.005)$ (Table 2$)$.

Table 2. Fluoride releasing values; median (min-max) $\left(\mu \mathrm{g} / \mathrm{mm}^{2}\right)$ and comparison of CNT and EXP groups

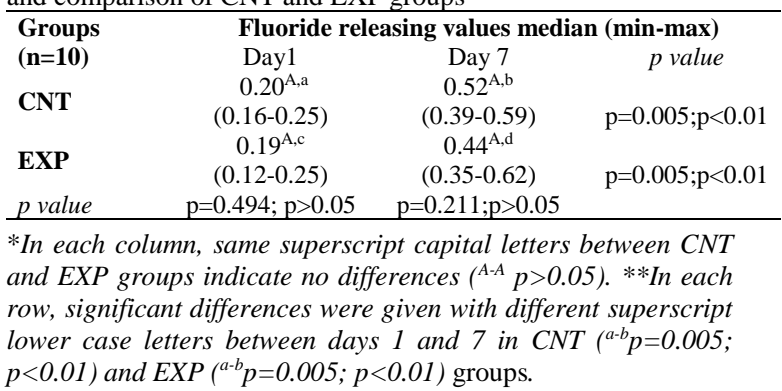

\section{DISCUSSION}

According to the findings of this study, it can be concluded that the usage of $\mathrm{CHX} 1 \% \mathrm{CHX}+1 \%$ $\mathrm{BC}+\mathrm{GIC}$ combination might exhibit negative surface alterations with acceptable fluoride releasing properties compared to the $\mathrm{CNT}$ group in tested periods. However, this combination indicates promising increased microhardness and fluoride releasing values which would not be ignored for the future study designs. Any antibacterial test method which was not done in this study could be considered as a limitation. But the findings from previous reports, it could be clearly detected that $\mathrm{CHX}$ and BC had shown antibacterial effects individually and/or in combination with other antibacterial substances. ${ }^{7,9,11,14-16,19,21}$ Nevertheless, the antibacterial effect of this certain combination could also be tested for future study designs.

Evidences from previous reports exhibited the need for GIC+antibacterial combination specifically for the ART procedures. ${ }^{10-20}$ Besides testing antibacterial actions, investigators commonly highlighted the basic properties of GIC+antibacterial combination should not be altered seriously which could lead a restoration failure if they would have a chance to be used as restorative material. ${ }^{12,15,16,18,19-21}$ From that point of view, the present study tested 
microhardness and fluoride releasing properties of commonly used antibacterials namely CHX and BC for GIC+antibacterial studies. ${ }^{9-12,14-16}$ Additionally, the reason that selecting of $1 \%$ for $\mathrm{CHX}$ and $1 \%$ for $\mathrm{BC}$ (a total of $2 \%$ ) is clearly related with the fact that the concentrations of antibacterials might be added as much as possible little amounts to provide antibacterial activity without seriously deteriorating the physical and chemical properties. ${ }^{14-16,19,21}$

As is known, the microhardness testing method is an accurate and valuable way to detect the clinical performance of GIC. ${ }^{23}$ Because of this reason the microhardness test was used for to compare the changes in surface hardness between EXP and CNT groups as similar with the previous studies. ${ }^{7,8,10,15,16,19}$ Present findings revealed that the EXP group exhibited poor microhardness values compared to the CNT group for both tested time periods. This finding is almost consistent with the previous reports. ${ }^{8,15,16,19}$ Moreover, prominent increase found from days 1 to 7 in EXP group could also be considered as promising results. Türkün et al.16 also reported the significantly increased microhardness values from days 1 to 7. In a previous study, it was also shown that the significantly increased microhardness values found in $1 \% \mathrm{CHX}+\mathrm{GIC}$ and $1 \% \mathrm{BC}+\mathrm{GIC}$ groups from day 1 to 7 as similar with the present study. They also indicated inwhich the day 7 would be a critical point for GIC+antibacterial combinations when testing microhardness values. ${ }^{8}$ Even, negative and discouraging findings found between EXP and CNT groups, significantly increased values obtained in EXP group up to 7 day. By the way, present findings may give an indication about the incorporation of $1 \% \mathrm{CHX}+1 \% \mathrm{BC}$ to the GIC resulting at softened but measurable surfaces during the study period. This finding also encouraged the idea of testing this combination after day 7 period to detect exact findings for future long-term in-vitro studies and/or clinical scenarios.
Fluoride-releasing skills of GICs are important for improving resistance of bacterial accumulation in an oral enviroment. ${ }^{23-28}$ The well known ion selective electrode method which was found as simple and realistic way to determine fluoride ions in GICs was also used as similar with the recent studies. ${ }^{17,19,23,26-28}$ Previous reports indicated the lower fluoride releasing values but insignificant differences of antibacterial components incorporated into the GIC compared to the controls. ${ }^{17,19}$ These findings are consistent with the present findings of the study. Such studies also showed time dependent decreases with regards to fluoride releasing profile of GIC+antibacterial ${ }^{17,19,20}$ combinations or antibacterial free GICs. ${ }^{23,24}$ Surprisingly, significantly increased amounts found in EXP group from days 1 to 7 in the present study as contradict with the previous data $^{17,19,20}$ might be explained by the different methods utilized in in-vitro studies such as concentration and combination properties of antibacterials, powder/liquid alterations during mixing period, temperature, storing conditions, $\mathrm{pH}$ of the storage environment and volume. Moreover, the findings found in the present study extrapolated the idea of using $\mathrm{CHX}+\mathrm{BC}$ at the concentration of a total of $2 \%$ would provide reasonable fluoride releasing pattern that would also be important for bacterial elimination in ART procedures.

Nevertheless, even the findings of this study have such negative and promising results, it should not be overlooked that the study design is constituted as in in-vitro condition which is not always mimic the oral environment and can be influenced by various factors. Thus, the mixture tested in this study should carefully screened in further in-vitro or in-vivo studies and they must be designed by caring the advantages and disadvantages of present results.

\section{CONCLUSION}

Within the limitations of this in-vitro study, although incorporation of $1 \% \mathrm{CHX}+1 \% \mathrm{BC}$ 
(powders, a total of $2 \%$ concentration) antibacterials to the powder of conventional GIC revealed a hopeless microhardness alterations compared to the antibacterial free GIC at days 1 and 7 , the acceptable and promising time related findings including microhardness and fluoride releasing values must be taken into account for future study designs as for the antibacterial added GIC innovations for ART procedures.

\section{ACKNOWLEDGEMENTS}

None.

\section{CONFLICT OF INTEREST}

There is no conflict of interest for the study.

\section{REFERENCES}

1. Frencken JE, Makoni F, Sithole WD. ART restorations and glass ionomer sealants in Zimbabwe: survival after 3 years. Community Dent Oral Epidemiol 1998; 26: 372-381.

2. Massara ML, Alves JB, Brandao PR. Atraumatic restorative treatment: clinical, ultrastructural and chemical analysis. Caries Res 2002; 36: 430-436.

3. Ferreira Fde M, do Vale MP, Jansen WC, Paiva SM, Pordeus IA. Performance of Brazilian and imported glass ionomer cements used in Atraumatic Restorative Treatment (ART) regarding microleakage in primary molars. J Appl Oral Sci 2006;14:312-318.

4. Van Amerongen WE. Dental caries under glass ionomer restorations. J Public Health Dent 1996;56:150-154.

5. Weerheijm KL, Groen HJ. The residual caries dilemma. Community Dent Oral Epidemiol 1999;27:436-441.

6. Weerheijm KL, Kreulen CM, de Soet JJ, et al. Bacterial counts in carious dentine under restorations: 2-year in vivo effects. Caries Res 1999;33:130-134.

7. Jedrychowski JR, Caputo AA, Kerpes S. Antibacterial and mechanical properties of restorative materials combined with chlorhexidine. J Oral Rehabil 1983;10: 373-381.
8. Tüzüner $T$, Ulusu $T$. Effect of antibacterial agents on the surface hardness of a conventional glass-ionomer cement. Journal of Applied Oral Science 2012;20(1):45-9.

9. Riberio J, Ericson D. In vitro antibacterial effect of chlorhexidine added to glass-ionomer cements. Scand J Dent Res 1991;99:533-540.

10.Sanders BJ, Gregory RL, Moore K, et al. Antibacterial and physical properties of resin modified glass-ionomers combined with chlorhexidine. J Oral Rehabil 2002;29:553-558. 11.Botelho MG. Inhibitory effects on selected oral bacteria of antibacterial agents incorporated in a glass ionomer cement. Caries Res 2003;37:108-114.

12.Palmer G, Jones FH, Billington RW, et al. Chlorhexidine release from experimental glass ionomer cement. Biomaterials 2004;25:423431.

13.Pinheiro SL, Simionato MRL, Imparato $\mathrm{JCP}$, et al. Antibacterial activity of glass ionomer containing antibiotics on caries lesion microorganisms. Am J Dent 2005;18:261-266. 14. Botelho MG. The antimicrobial activity of a dentin conditioner combined with antibacterial agents. Oper Dent 2005;30:75-82.

15. Takahashi $Y$, Imazoto $S$, Kaneshiro AV, et al. Antibacterial effects and physical properties of glass-ionomers cements containing chlorhexidine for the ART approach. Dent Mater 2006;22:647-652.

16.Türkün LS, Türkün $M$, Ertugrul $F$, et al. Long-term antibacterial effects and physical properties of restorative materials combined with chlorhexidine. J Esthet Restor Dent 2008; 20:29-44.

17.Hoszek A, Ericson D. In vitro fluoride release and the antibacterial effect of glassionomers containing chlorhexidine gluconate. Oper Dent 2008; 33: 696-701.

18. Yesilyurt $\mathrm{C}$, Er $\mathrm{K}$, Tasdemir $\mathrm{T}$, et al. Antibacterial activity and physical properties of glass-ionomer cements containing antibiotics. Oper Dent 2009; 34: 18-23.

19.Tüzüner $T$, Kuşgöz A, Er K, Taşdemir $T$, Buruk K, Kemer B et al. Antibacterial activity 
and physical properties of conventional glassionomer cements containing chlorhexidine diacetate/cetrimide mixtures. J Esthet Rest Dent 2011; 23: 46-55.

20.Hu J, Du X, Huang C, Fu D, Ouyang X, Wang Y. Antibacterial and physical properties of EGCG-containing glass ionomer cements. J Dent 2013; 41: 927-934.

21.Farrugia C, Camilleri J. Antimicrobial properties of conventional restorative filling materials and advances in antimicrobial properties of composite resins and glass ionomer cements - A literature review. Dent Mater 2015; 31: e89-e99.

22. Silva RC, Zuanon AC, Esberard RR, Candido MS, Machado JS. In vitro microhardness of glass ionomer cements. J Mater Sci Mater Med 2007;18: 139-142.

23.Karantakis $\mathrm{P}$, Helvatjoglou-Antoniades $\mathrm{M}$, Theodoridou-Pahini S, Papadogiannis Y. Fluoride release from three glass ionomers, a compomer, and a composite resin in water, artificial saliva, and lactic acid. Oper Dent 2000;25:20-25.

24. Bell A, Creanor SL, Foye RH, Saunders WP. The effect of saliva on fluoride release by a glass-ionomer filling material. Journal of oral rehabilitation 1999;26:407-412.

25. Dionysopoulos $\mathrm{P}$, Kotsanos N, Pataridou A. Fluoride release and uptake by four new fluoride releasing restorative materials. J Oral Rehab 2003;30:866-872.

26. Attin T, Buchalla W, Siewert C, Hellwig E. Fluoride release/uptake of polyacid-modified resin composites (compomers) in neutral and acidic buffer solutions. J Oral Rehab 1999;26:388-393.

27.Williams JA, Billington RW, Pearson GJ. The glass ionomer cement: the sources of soluble fluoride. Biomaterials 2002;23:2191-200.

28. Arısu HD, Bala O, Üçtaşı MB, Kalaycı Ş. Cam iyonomer siman ve poliasit modifiye kompozit rezinlerin florid salma özellikleri. GÜ Diş Hek Fak Derg 2007;24:157-61.

\section{Corresponding Author}

Tamer Tüzüner

Karadeniz Technical University,

Department of Pediatric Dentistry,

Faculty of Dentistry,

Kanuni Kampus, Trabzon, Turkey.

Phone: +90-462-3774780

Fax: +90-462-3253017

E-mail: tamertuzuner@gmail.com, tamertuzuner@ktu.edu.tr 